\title{
DUKUNGAN SOSIAL TERHADAP PERILAKU PENCEGAHAN PENULARAN PENYAKIT TB PARU DI PUSKESMAS PERAK TIMUR SURABAYA
}

\author{
Dinar Mutiara K*, Setiawan, AT Diana Nerawati
}

Jurusan Kesehatan Lingkungan Poltekkes Kemenkes Surabaya

*Email korespondensi: dinarmutiarakuswandari@gmail.com

\section{ABSTRAK}

Provinsi Jawa Timur merupakan provinsi tertinggi kedua kasus TB Paru di Indonesia. Pada tahun 2018 kasus TB Paru di Puskesmas Perak Timur Kecamatan Pabean Cantikan Kota Surabaya berjumlah 143 kasus. Kurangnya dukungan keluarga merupakan faktor penyebab masih tingginya kejadian TB Paru di Indonesia. Praktik perilaku pencegahan penularan penyakit TB Paru yang rendah merupakan faktor penyebab penyebaran TB Paru. Tujuan penelitian ini untuk mengetahui pengaruh dukungan sosial terhadap perilaku pencegahan penularan penyakit pada penderita TB Paru di wilayah kerja Puskesmas Perak Timur.

Penelitian ini menggunakan desain penelitian kuantitatif dan pendekatan cross sectional study. Analisis data menggunakan Uji Regresi Linier Berganda. Sebanyak 59 responden diambil dengan simple random sampling untuk mengamati Dukungan Sosial meliputi dukungan emosional, instrumental, informasi, dan jaringan sosial.

Hasil penelitian menunjukkan bahwa mayoritas penderita TB Paru di Puskesmas Perak Timur adalah laki-laki $(67,8 \%)$, berpendidikan terakhir SMA $(52,5 \%)$, dan berusia kategori dewasa akhir antara 36-45 tahun (27,2\%). Diketahui bahwa penderita TB Paru di Puskesmas Perak Timur sebanyak $74,8 \%$ telah menerapkan perilaku pencegahan penularan penyakit yang baik. Berdasar uji regresi linier berganda di ketahui bahwa nilai $R$ square variabel dukungan sosial adalah sebesar 0,595. Dengan nilai sumbangan relatif dukungan emosional $55,55 \%$, dukungan instrumental $5,31 \%$, dukungan informasi $21,21 \%$, dan dukungan jaringan sosial $17,93 \%$.

Penelitian ini menunjukkan bahwa dukungan sosial berpengaruh kuat terhadap perilaku pencegahan penularan penyakit pada penderita TB Paru. Bagi puskesmas sebaiknya mengoptimalkan sosialisasi terkait peran dukungan sosial bagi penderita TB Paru, sehingga masyarakat dapat berperan aktif memberikan dukungan sosial untuk meningkatkan perilaku pencegahan penularan penyakit pada penderita TB Paru.

Kata Kunci: Dukungan Sosial, Perilaku Pencegahan Penularan Penyakit TB Paru

\section{PENDAHULUAN}

Terdapat empat faktor utama yang saling berinteraksi dan mempengaruhi derajat kesehatan masyarakat. Keempat faktor tersebut terdiri dari faktor lingkungan, faktor perilaku/gaya hidup, faktor pelayanan kesehatan, dan faktor genetik. Faktor perilaku, merupakan faktor kedua terbesar pengaruhnya setelah lingkungan yang mempengaruhi derajat kesehatan masyarakat (Hendrik L. Blum, 1974).

Tuberkulosis (TB) adalah suatu penyakit infeksi menular yang disebabkan oleh bakteri Mycobacterium tuberkulosis. Penyakit ini dapat menyerang berbagai organ, akan tetapi umumnya menyerang paru-paru. Tuberkulosis telah menjadi penyebab kematian sepertiga dari penduduk dunia sejak tahun 1993 (Mertaniasih, 2013). Namun kemajuan penanganan penyakit TB Paru baru terjadi dalam dua abad terakhir (Kemenkes RI, 2015).

Indonesia termasuk dalam daftar High Burden Countries (HBC) pada tahun 2018 dikarenakan kasus TB Paru, TB Paru/HIV, dan MDR-TB Paru yang tinggi. (Pusat Data dan Informasi Kemenkes RI, 2018). Indonesia menempati peringkat ke-3 dunia dengan beban Tuberkulosis terbesar diantara 8 negara lain yaitu India (27\%), China (9\%), Indonesia (8\%), Philipina 
(6\%), Pakistan (5\%), Nigeria (4\%), Bangladesh (4\%) dan Afrika Selatan (3\%) (Kementerian Kesehatan RI, 2018).

Tekanan psikologis dan merasa tidak berguna mempengaruhi persepsi penderita terhadap kemungkinan keberhasilan pengobatan (Yuliana, 2012). Kurangnya dukungan keluarga merupakan faktor penyebab masih tingginya kejadian TB Paru di Indonesia (Nugroho, 2016). Menurut Valerie A Paz-Soldan, et al (2013) berdasar penelitan yang di lakukan diketahui bahwa meskipun dukungan keluarga berperan penting bagi penderita TB Paru, namun keluarga bukanlah satu-satunya sumber dukungan yang dibutuhkan. Dukungan dari teman komunitas, sesama penderita, dan juga petugas kesehatan sangat mempengaruhi perilaku penderita TB Paru.

Sejalan dengan penelitian R.D. Deshmukh, et al (2018) yang mengatakan bahwa dukungan baik dari lingkungan sosial maupun dari petugas medis merupakan faktor kunci keberhasilan pengobatan TBMDR. Interaksi dengan sosial masyarakat dapat mempengaruhi seseorang menafsirkan peristiwa atau masalah baik kearah positif atau negatif. Sehingga jaringan sosial dan dukungan sosial berperan sebagai titik awal atau inisiator yang berpengaruh terhadap perubahan perilaku ke arah peningkatan kesehatan (Irwan, 2017).

Berdasarkan studi pendahuluan di wilayah kerja Puskesmas Perak Timur di ketahui bahwa Puskesmas Perak Timur telah menyediakan kader TB Paru di setiap RW yang ada. Kader tersebut berfungsi untuk membantu memantau kondisi penderita TB Paru. Akan tetapi penegakan perilaku pencegahan penularan penyakit pada penderita TB Paru di wilayah kerja Puskesmas Perak Timur belum maksimal.
Banyak penderita TB yang terlihat tidak mengenakan masker ketika berada diluar rumah. Hal ini terjadi antara lain adanya rasa malu dari diri penderita. Tingginya mobilitas penduduk dan rendahnya perilaku pencegahan penularan penyakit, akan mempermudah penyebaran TB Paru di wilayah kerja Puskesmas Perak Timur. Tingginya jumlah penduduk serta rendahnya sanitasi pemukiman, menyebabkan kuman TB Paru berkembang biak dengan mudah. Maka dari itu penelitian ini bertujuan untuk mengetahui pengaruh dukungan sosial terhadap perilaku pencegahan penularan penyakit pada Penderita TB Paru di wilayah kerja Puskesmas Perak Timur.

\section{METODE PENELITIAN}

Jenis penelitian ini menggunakan desain penelitian observasional analitik. Penelitian ini menggunakan pendekatan cross sectional study. Variabel independent dalam penelitian ini adalah dukungan sosial yang meliputi dukungan emosi, dukungan instrumental, dukungan informasi, dan dukungan jaringan sosial. Variabel dependen pada penelitian ini adalah perilaku pencegahan penularan penyakit TB Paru. Populasi dalam penelitian ini adalah penderita TB Paru di Puskesmas Perak Timur sebanyak 143 orang. Sampel pada penelitian ini adalah 59 orang yang diambil menggunakan metode simple random sampling.

Alat pengumpul data yang digunakan untuk mengukur dukungan sosial adalah kuesioner sesuai teori Dukungan Sosial milik Sarafino \& Smith (1990). Kuesioner yang digunakan telah diuji validitas dan reliabilitas. Nilai validitas $r$-table lebih dari 0,312 sedangkan untuk reliabilitas lebih dari rata-rata nilai Cronbach's alpha 0,913. 


\section{HASIL DAN PEMBAHASAN \\ Perilaku Pencegahan}

Tabel 1

Distribusi Frekuensi Perilaku Pencegahan

Penularan Penyakit TB Paru

\begin{tabular}{lcc}
\hline $\begin{array}{c}\text { Perilaku } \\
\text { Pencegahan }\end{array}$ & Frekuensi & $\begin{array}{c}\text { Persentase } \\
(\%)\end{array}$ \\
\hline Baik & 44 & 74,8 \\
\hline Kurang Baik & 15 & 25,5 \\
\hline Total & $\mathbf{5 9}$ & $\mathbf{1 0 0}$ \\
\hline
\end{tabular}

Diketahui bahwa responden yang memiliki perilaku pencegahan penularan penyakit baik sebanyak 44 orang $(74,8 \%)$, lebih banyak dibandingkan responden dengan perilaku pencegahan penularan penyakit yang kurang baik. Beberapa perilaku yang masih tergolong kurang baik ini adalah kebiasaan memakai masker dalam berkegiatan sehari-hari; kebiasaan membuang dahak di sembarang tempat; dan perilaku menjemur kasur dan bantal. Rendahnya praktik memakai masker tersebut berhubungan dengan tingkat pengetahuan responden (Yuliastuti, 2014), sedangkan berdasarkan hasil wawancara diketahui bahwa alasan penderita enggan memakai masker dikarenakan adanya rasa malu. Kebiasaan membuang dahak atau meludah di sembarang tempat dapat meningkatkan penyebaran kuman TB Paru yang didukung pula oleh faktor lain seperti kepadatan huni, kondisi fisik lingkungan, sosial-ekonomi, kebiasaan merokok, dan penyakit infeksi lainnya (Ayomi, 2012; Farida, 2013). Rendahnya perilaku menjemur kasur dan bantal disebabkan karena tidak tersedianya lahan disekitar rumah penderita yang cukup. Hal tersebut sesuai dengan kondisi pemukiman penderita TB Paru di wilayah kerja Puskesmas Perak Timur yang mayoritas merupakan pemukiman padat penduduk dengan lebar bahu jalan yang hanya dapat dilalui dengan berjalan kaki.

\section{Dukungan Emosional}

Tabel 2

Distribusi Frekuensi Dukungan Emosional yang dirasakan oleh

Penderita TB Paru di Puskesmas Perak Timur

\begin{tabular}{lcc}
\hline $\begin{array}{l}\text { Dukungan } \\
\text { Emosional }\end{array}$ & Frekuensi & $\begin{array}{c}\text { Persentase } \\
(\mathbf{\%})\end{array}$ \\
\hline Baik & 36 & 61,0 \\
\hline Kurang Baik & 23 & 39,0 \\
\hline Total & $\mathbf{5 9}$ & $\mathbf{1 0 0}$ \\
\hline
\end{tabular}

Dapat diketahui bahwa responden yang mengaku mendapatkan dukungan emosional baik sebanyak 36 orang $(61,0 \%)$ lebih banyak dibandingkan dengan responden yang mengaku mendapatkan dukungan emosional kurang baik. Dukungan emosional adalah salah satu bentuk dukungan sosial yang meliputi ekspresi empati, dan perduli kepada seseorang yang dirasakan dari orang-orang di lingkungan sosial sekitarnya.

Dari hasil wawancara dan pengisian kuesioner, diketahui bahwa rata-rata responden mengaku lebih banyak mendapat dukungan emosional bernilai positif dari perawat dan keluarganya dibandingkan dari teman-temannya. Sebanyak rata-rata 34 responden mengaku mendapat dukungan emosional bernilai positif dari perawat berupa keramahan dalam memberikan pelayanan, dan ratarata sebanyak 26 responden mengaku mendapat dukungan emosional bernilai positif dari keluarga berupa tidak menjauhi penderita; pemberian kasih sayang; memperhatikan perkembangan kesehatan; menjenguk; tidak menunjukkan ekspresi yang kurang menyenangkan; dan menciptakan rasa nyaman.

Pelayanan yang tepat akan meningkatkan koneksi atau hubungan yang kuat antara pekerja professional dengan pasien, hal tersebut akan meningkatkan persepsi yang lebih baik pada pasien tentang penerimaan perhatian. Tingginya peran perawat melebihi keluarga, dimungkinkan karena rendahnya pengetahuan keluarga tentang penyakit TB Paru. Hal tersebut dapat menimbulkan lemahnya kemampuan keluarga untuk 
beradaptasi dengan kondisi pasien. Sehingga, responden menilai peran keluarga kurang mendominasi dibandingkan bantuan dukungan emosional yang diberikan oleh perawat TB Paru dalam melayani pengobatan.

\section{Dukungan Instrumental}

Tabel 3

Distribusi Frekuensi Dukungan Instrumental yang dirasakan oleh Penderita TB Paru di Puskesmas Perak Timur

\begin{tabular}{lcc}
\hline $\begin{array}{c}\text { Dukungan } \\
\text { Instrument } \\
\text { al }\end{array}$ & $\begin{array}{c}\text { Frekuen } \\
\text { si }\end{array}$ & $\begin{array}{c}\text { Persentas } \\
\text { e (\%) }\end{array}$ \\
\hline Baik & 21 & 35,6 \\
\hline Kurang Baik & 38 & 64,4 \\
\hline Total & $\mathbf{5 9}$ & $\mathbf{1 0 0}$ \\
\hline
\end{tabular}

Diketahui bahwa responden yang mengaku mendapat dukungan instrumental kurang baik sebanyak 38 orang (64,4\%) lebih banyak dibandingkan responden yang mengaku mendapat dukungan instrumental baik. Dukungan instrumental adalah salah satu bentuk dukungan sosial yang meliputi pemberian dukungan langsung atau nyata, seperti memberikan atau meminjamkan kebutuhan hidup baik berupa uang atau barang; atau kegiatan seperti membantu meringankan pekerjaan.

Menurut pengakuan dari rata-rata 34 responden $(57,2 \%)$ dukungan instrumental bernilai negatif didominasi bersumber dari teman. Dukungan instrumental bernilai negatif yang berasal dari teman ini meliputi: tidak pernah memberikan bantuan finansial; tidak pernah bersedia menjadi teman berdiskusi; tidak pernah bersedia mengantar ke puskesmas jika dalam kondisi darurat; dan tidak pernah mengingatkan responden untuk optimis dalam pengobatan.

Menurut Pedoman Nasional Pengendalian Tuberculosis tahun 2011, dikatakan bahwa sekitar $75 \%$ pasien TB Paru adalah kelompok usia yang paling produktif secara ekonomi (15-50 tahun). Siperkirakan seorang pasien TB Paru dewasa, akan kehilangan rata-rata waktu kerjanya antara tiga sampai dengan empat bulan. Hal tersebut berakibat pada kehilangan pendapatan tahunan rumah tangganya sebanyak 20-30\%. Dan jika seorang pasien berperan sebagai tulang punggung keluarga, apabila ia meninggal akibat TB Paru maka akan kehilangan pendapatannya sekitar 15 tahun.

Dalam penelitian ini diketahui bahwa dukungan instrumental adalah prediktor independen (variabel bebas) yang mempengaruhi perilaku kesehatan responden, namun masih di perdebatkan apakah kehadirannya mengurangi atau meningkatkan level depresi pada seseorang (Khamarko \& Myer, 2013; Link \& Phelan, 1995; Bajunirwe, 2009; Tsai, 2012).

\section{Dukungan Informasi}

\section{Tabel 4}

Distribusi Frekuensi Dukungan Informasi yang dirasakan oleh Penderita TB Paru di Puskesmas Perak Timur

\begin{tabular}{lcc}
\hline $\begin{array}{l}\text { Dukungan } \\
\text { Informasi }\end{array}$ & Frekuensi & $\begin{array}{c}\text { Persentase } \\
(\mathbf{\%})\end{array}$ \\
\hline Baik & 36 & 61,0 \\
\hline Kurang Baik & 23 & 39,0 \\
\hline Total & $\mathbf{5 9}$ & $\mathbf{1 0 0}$ \\
\hline \multicolumn{1}{c}{ Diketahui } & ba & responden yang
\end{tabular}

Diketahui bahwa responden yang mengaku mendapat dukungan informasi baik sebanyak 36 orang $(61,0 \%)$ lebih banyak dibandingkan responden yang mengaku mendapat dukungan informasi kurang baik. Dukungan informasi adalah salah satu bentuk dukungan sosial yang meliputi pemberian saran pemecahan masalah, pemberian arahan atau petunjuk, dan pemberian nasihat atau umpan balik tentang apa yang dilalui seseorang.

Penelitian ini menunjukkan bahwa berdasar rata-rata 37 responden $(62,7 \%)$ mengaku bahwa perawat memberikan dukungan informasi bernilai positif yang lebih baik dibandingkan keluarga. Dukungan informasi bernilai positif yang berasal dari perawat meliputi: penjelasan pentingnya memakai masker; penjelasan pentingnya rutin meminum obat; penjelasan pentingnya mewadahi dahak; dan memberikan edukasi seputar penyakit TB Paru. Sedangkan rata-rata hanya 15 responden $(25,4 \%)$ yang mengaku 
mendapat dukungan informasi bernilai positif dari teman yang meliputi: memberitahu pentingnya memakai masker; mengingatkan untuk hidup sehat; dan membagi informasi tentang pengobatan TB Paru.

Dukungan informasi merupakan dukungan yang berpengaruh terhadap kejadian sakit, dukungan informasi telah diketahui berkaitan dengan meningkatnya kesehatan mental dan fisik, sejalan dengan kualitas kehidupan seseorang (Khamarko \& Myers. 2013). Taylor (2007) menjelaskan, dukungan informasi dapat meneguhkan individu untuk mengambil keputusan dalam menentukan kesehatan mereka sendiri.

Peran dukungan informasi sangat dibutuhkan untuk mencapai keberhasilan program TB Nasional. Pada Puskesmas Perak Timur, dukungan informasi terimplementasi dengan pelaksanaan pemberian pelatihan atau konseling baik bagi penderita TB Paru maupun bagi Pengawas Minum Obat (PMO).

\section{Dukungan Jaringan Sosial Tabel 5}

Distribusi Frekuensi Dukungan Jaringan

Sosial yang dirasakan oleh Penderita TB Paru di Puskesmas Perak Timur

\begin{tabular}{lcc}
\hline $\begin{array}{c}\text { Dukungan } \\
\text { Jaringan } \\
\text { Sosial }\end{array}$ & Frekuensi & $\begin{array}{c}\text { Persentase } \\
(\%)\end{array}$ \\
\hline Baik & 22 & 37,3 \\
\hline Kurang Baik & 37 & 62,7 \\
\hline Total & $\mathbf{5 9}$ & $\mathbf{1 0 0}$ \\
\hline
\end{tabular}

Diketahui bahwa responden yang mengaku mendapat dukungan jaringan sosial kurang baik sebanyak 37 orang $(62,7 \%)$ lebih banyak dibanding responden yang mengaku mendapat dukungan jaringan sosial baik. Dukungan jaringan sosial adalah salah satu bentuk dukungan sosial yang meliputi meliputi ketersediaan dari individu lain untuk menghabiskan waktu bersama, dan memberikan perasaan bahwa individu adalah sebagai anggota dari kelompok tertentu sehingga individu tidak merasa sendiri atau terasingkan. Berdasar wawancara dan kuesioner diketahui bahwa sebanyak 34 responden $(57,6 \%)$ tidak ragu untuk sembuh dari penyakit TB Paru, dan 38 responden $(64,4 \%)$ tidak ragu untuk terus berobat meskipun memakan waktu yang lama. Akan tetapi, perlu diperhatikan bahwa masih ada sebanyak 18 responden (30,5\%) yang mengaku memilih untuk merahasiakan statusnya sebagai penderita TB Paru.

Penelitian Castrighini et al di Ribeirão Preto, Brazil pada tahun 2018 mengatakan bahwa jaringan sosial menjadi salah satu domain yang menunjukkan korelasi dengan kualitas hidup penderita TB/HIV. Hal ini dikarenakan struktur dari dukungan jaringan sosial lebih nyata dan perlu untuk dipertimbangan karena adanya kemungkinan isolasi sosial bagi penderita TB/HIV yang didasari oleh prasangka takut tidak diterima oleh masyarakat.Rendahnya pemahaman keluarga dapat menjadi faktor pemicu terhambatnya penerapan perilaku pencegahan penularan penyakit pada penderita TB Paru.

Dukungan jaringan sosial dapat berasal dari berbagai individu yang ada di sekitar lingkungan penderita, termasuk dari keluarga, teman sebaya, pasangan hidup, dan orang lain yang memiliki hubungan dengan individu tersebut. Pentingnya memberikan dukungan jaringan sosial dikarenakan penyakit TB Paru merupakan permasalahan sosial yang pemberantasannya pun diperlukan kerjasama dan peran aktif dari berbagai jaringan.

\section{Dukungan Sosial}

\section{Tabel 6}

Distribusi Frekuensi Dukungan Sosial yang dirasakan oleh Penderita TB Paru di Puskesmas Perak Timur

\begin{tabular}{lcc}
\hline $\begin{array}{c}\text { Dukungan } \\
\text { Sosial }\end{array}$ & Frekuensi & $\begin{array}{c}\text { Persentase } \\
(\mathbf{\%})\end{array}$ \\
\hline Baik & 33 & 55,9 \\
\hline Kurang Baik & 26 & 44,1 \\
\hline Total & $\mathbf{5 9}$ & $\mathbf{1 0 0}$ \\
\hline Diketahui & bahwa & responden yang
\end{tabular}
mengaku mendapat dukungan sosial baik sebanyak 33 orang $(55,9 \%)$ lebih banyak dibandingkan responden yang mengaku mendapat dukungan sosial kurang baik. Dukungan sosial didefinisikan sebagai 
informasi baik verbal maupun non verbal yang diberikan oleh orang-orang yang akrab dengan subyek di dalam lingkungan sosialnya. Dukungan sosial dapat berupa kehadiran hal-hal yang dapat memberikan keuntungan emosional berpengaruh pada tingkah laku. (Irwan, 2017).

Namun perlu diperhatikan bahwa penilaian dukungan sosial oleh responden juga dapat dipengaruhi dari berbagai macam hal terutama persepektif responden. Hal ini sesuai dengan teori dukungan sosial milik Sarafino \& Smith (1990) yang menyatakan bahwa terdapat dua faktor yang mempengaruhi penilaian dukungan sosial, yaitu keberadaan perceived dan received support.

\section{Pengaruh Dimensi Dukungan Sosial terhadap Perilaku Pencegahan Penularan Penyakit pada Penderita TB Paru.}

\section{Tabel 7}

Uji Korelasi Pearson Dukungan Sosial terhadap Perilaku Pencegahan Penularan Penyakit pada Penderita TB Paru

\begin{tabular}{|c|c|c|c|c|c|}
\hline $\begin{array}{l}\text { Pearson } \\
\text { Corelati } \\
\text { on }\end{array}$ & $\begin{array}{l}\text { Peri } \\
\text { laku }\end{array}$ & $\begin{array}{c}\text { Emos } \\
\text { i } \\
\text { onal }\end{array}$ & $\begin{array}{c}\text { Instr } \\
\text { umen } \\
\text { tal }\end{array}$ & $\begin{array}{c}\text { Info } \\
\mathbf{r} \\
\text { mas } \\
\text { i }\end{array}$ & $\begin{array}{c}\text { Jari } \\
\text { ngan } \\
\text { Sosia } \\
\text { | }\end{array}$ \\
\hline Perilaku & $\begin{array}{c}1.00 \\
0\end{array}$ & .756 & .686 & .725 & .711 \\
\hline $\begin{array}{l}\text { Emosio } \\
\text { nal }\end{array}$ & .756 & 1.000 & .818 & .876 & .854 \\
\hline $\begin{array}{l}\text { Instru } \\
\text { mental }\end{array}$ & .686 & .818 & 1.000 & .878 & .859 \\
\hline $\begin{array}{l}\text { Informa } \\
\text { si }\end{array}$ & .725 & .876 & .878 & $\begin{array}{c}1.00 \\
0\end{array}$ & .850 \\
\hline $\begin{array}{l}\text { Jaringa } \\
\text { n Sosial }\end{array}$ & .711 & .854 & .859 & .850 & 1.000 \\
\hline
\end{tabular}
variabel dukungan sosial (dukungan emosional, dukungan instrumental, dukungan informasi, dan dukungan jaringan sosial) memiliki nilai korelasi yang mendekati angka 1. Hal tersebut berarti bahwa ada hubungan yang kuat antara komponen dukungan sosial dengan perilaku pencegahan penularan penyakit pada penderita TB Paru.
Untuk mengetahui besar persentase pengaruh dari masing-masing komponen tersebut maka harus dihitung sumbangan prediktornya. Sumbangan prediktor terdiri menjadi sumbangan efektif (SE) dan sumbangan relative (SR) yang akan disajikan melalui tabel berikut:

Tabel 8

Nilai Sumbangan Efektif (SE) dan Sumbangan Relatif (SR)

\begin{tabular}{lcc}
$\begin{array}{l}\text { Variabel } \\
\text { Independ } \\
\text { en }\end{array}$ & $\begin{array}{c}\text { Sumbang } \\
\text { an Efektif }\end{array}$ & $\begin{array}{l}\text { Sumbang } \\
\text { an Relatif }\end{array}$ \\
\hline Emosional & 33,037 & $55,55 \%$ \\
\hline $\begin{array}{l}\text { Instrument } \\
\text { al }\end{array}$ & 3,156 & $5,31 \%$ \\
\hline Informasi & 12,615 & $21,21 \%$ \\
\hline $\begin{array}{l}\text { Jaringan } \\
\text { Sosial }\end{array}$ & 10,665 & $17,93 \%$ \\
\hline \multicolumn{2}{c}{ Total } & $\mathbf{1 0 0 \%}$ \\
\hline
\end{tabular}

Dari hasil perhitungan nilai sumbangan prediktor diketahui bahwa dukungan emosional memberikan kontribusi paling tinggi yaitu sebesar 55,55\% terhadap perubahan perilaku pencegahan penularan penyakit. Tingginya peran dukungan emosional dikarenakan pasien dengan penyakit infeksius memiliki masalah emosional yang lebih serius dibandingkan dengan pasien tanpa penyakit infeksius (Wang et al, 2017). Kondisi tersebut sesuai dengan latar belakang responden penelitian ini, dimana penyakit TB Paru merupakan penyakit infeksius yang mudah menular ke orang lain. Menurunnya kemampuan fisik tubuh, timbulnya efek samping pengobatan, lamanya masa berobat dengan variasi obatobatan yang cukup banyak, ancaman kematian, dan stigma di masyarakat akan menyebabkan penderita TB Paru mengalami stress yang termanifestasi. Dukungan informasi memiliki kontribusi nomor dua tertinggi $(21,21 \%)$ terhadap perubahan perilaku pencegahan penularan penyakit pada penderita TB Paru. Taylor (2007) mengatakan bahwa dukungan informasi dapat meneguhkan individu untuk mengambil keputusan dalam menentukan kesehatan mereka sendiri.

Dukungan jaringan sosial memiliki kontribusi nomor tiga $(17,93 \%)$ terhadap 
perubahan perilaku pencegahan penularan penyakit pada penderita TB Paru. Dukungan jaringan sosial akan menciptakan perasaan bahwa penderita TB Paru merupakan bagian dari kelompok, kompunitas, atau grup yang ada di masyarakat. Dukungan jaringan sosial ini menjadi penting karena mempengaruhi dukungan jaringan sosial yang lain, seperti pada dukungan informasi yang diberikan oleh kader kesehatan bidang TB Paru akan mendukung meningkatnya dukungan jaringan sosial antara pasien dengan kader tersebut. Akan tetapi, berdasarkan penelitian diketahui bahwa dukungan jaringan sosial yang dirasakan oleh responden termasuk dalam kategori kurang baik. Penilaian dukungan bernilai negatif ini didasari karena rendahnya peran teman dalam menjaga komunikasi dengan penderita menurut pengakuan dari rata-rata 26 responden $(44,1 \%)$, perlakuan orangorang disekitar responden yang menjadikan responden merahasiakan statusnya sebagai penderita menurut pengakuan dari 18 orang responden $(30,5 \%)$, serta tidak tersedianya komunitas penderita TB Paru di Puskesmas Perak Timur. Hal ini berkaitan dengan rendahnya perilaku menggunakan masker dalam kegiatan sehari-hari responden.

Dukungan instrumental memiliki kontribusi paling rendah $(5,31 \%)$ terhadap perubahan perilaku pencegahan penularan penyakit pada penderita TB Paru. Pada penelitian ini diketahui bahwa dukungan instrumental yang dirasakan oleh penderita TB Paru tergolong dalam kategori kurang baik. Penilaian dukungan instrumental negatif ini didasari oleh pengakuan dari rata-rata 34 responden $(57,6 \%)$ yang mengatakan bahwa teman kurang baik dalam memberikan bantuan instrumental, dan sebanyak 25 responden $(42,4 \%)$ mengaku keluarga tidak pernah menemani responden berobat ke puskesmas.

\section{Pengaruh Dukungan Sosial dengan Perilaku Pencegahan Penularan Penyakit pada Penderita TB Paru}

Tabel 9

Model Summary

\begin{tabular}{|l|r|r|r|r|r|}
\hline Model & R & R Square & $\begin{array}{c}\text { Adjusted R } \\
\text { Square }\end{array}$ & $\begin{array}{c}\text { Std. Error of } \\
\text { the Estimate }\end{array}$ & Durbin-Watson \\
\hline 1 & $.771^{\text {a }}$ & .595 & .565 & 6.453 & 2.048 \\
\hline
\end{tabular}

a. Predictors: (Constant), Jaringan Sosial, Informasi, Emosional, Instrumental

b. Dependent Variable: Perilaku Responden

Berdasarkan uji regresi linier diketahui nilai koefisien determinasi ( $R$ square) variabel dukungan sosial adalah sebesar 0,595. Hal ini berarti bahwa secara bersama-sama variabel emosional (X1), instrumental (X2), informasi (X3), dan jaringan sosial (X4) dalam variabel dukungan sosial memberi pengaruh dengan kontribusi sebesar $59,5 \%$ bagi perubahan variabel perilaku pencegahan penularan penyakit ( $\mathrm{Y}$ ) pada penderita TB Paru di Puskesmas Perak Timur. Sehingga dapat disimpulkan bahwa 40,5\% sisanya adalah variabel lain yang tidak diteliti dalam penilitan ini.

Tabel 10

Anova $^{a}$

\begin{tabular}{|c|c|c|c|c|c|c|}
\hline \multicolumn{2}{|c|}{ Model } & \multirow{2}{*}{$\begin{array}{c}\begin{array}{c}\text { Sum of } \\
\text { Squares }\end{array} \\
3305.535 \\
\end{array}$} & \multirow{2}{*}{ df 4} & \multirow{2}{*}{$\begin{array}{r}\text { Mean Square } \\
826.384 \\
\end{array}$} & \multirow{2}{*}{$\frac{\mathbf{F}}{19.845}$} & \multirow{2}{*}{$\begin{array}{l}\text { Sig. } \\
.000^{\mathrm{b}} \\
\end{array}$} \\
\hline 1 & Regression & & & & & \\
\hline & Residual & 2248.635 & 54 & 41.641 & & \\
\hline & Total & 5554.169 & 58 & & & \\
\hline
\end{tabular}

a. Dependent Variable: Perilaku Responden

b. Predictors: (Constant), Jaringan Sosial, Informasi, Emosional, Instrumental 
Hasil perhitungan menunjukkan bahwa nilai $F$ hitung yang diperoleh adalah sebesar 19.845 sementara nilai $F$ tabel dengan df 4 dan 55 adalah sebesar 2.05, maka diketahui bahwa $\mathrm{F}$ hitung $>\mathrm{F}$ tabel sehingga dapat disimpulkan bahwa model persamaan regresi dalam penelitian ini dapat diterapkan. Sementara nilai probabilitas hitung atau taraf signifikasi yang didapat adalah sebesar 0.000. Karena nilai taraf signifikansi $<0.05$ maka persamaan regresi yang dipergunakan dapat diterapkan dalam analisis data. Hal ini berarti ada pengaruh yang signifikan antara dukungan sosial terhadap perilaku pencegahan penularan penyakit pada penderita TB Paru.

Ada dua faktor yang dapat mempengaruhi penilaian dukungan sosial pada suatu individu, yaitu perceived support atau dukungan yang dirasakan dan received support atau dukungan yang sebenarnya diterima. Keberadaan perceived dan received support memiliki dampak tersendiri terhadap kesehatan individu baik secara fisik ataupun psikologi. Hal ini menjelaskan bahwa dari hasil wawancara dan kuesioner yang dilakukan, dari seluruh penderita yang mengaku mendapat dukungan sosial rendah belum tentu seluruhnya benar-benar mendapatkan dukungan sosial yang rendah. Ada kemungkinan bahwa sebanyak 44,1\% penderita yang mengaku mendapat dukungan sosial rendah sebenarnya mendapatkan dukungan sosial yang baik akan tetapi mereka menginterpretasikannya secara berbeda. (Sarafino \& Smith, 1994; Berkman et al, 2000; Link \& Phelan 1995; Martin JK et al, 2007).

Ada beberapa hal yang dapat mempengaruhi perspektif penderita TB Paru dalam menerima dukungan sosial, meliputi frekuensi interaksi; posisi atau status individu dalam suatu jaringan sosial; serta kedekatan atau keintiman individu terhadap orang lain untuk dapat menimbulkan rasa percaya antara satu dengan yang lain. Sehingga, baik dalam memberikan ataupun menerima dukungan sosial diperlukan suatu proses yang lama untuk kemudian dapat mempengaruhi perspektif penderita bahwa ia mendapat dukungan dan kasih sayang dari orang-orang terdekatnya. Selain memerlukan waktu dan proses yang cukup panjang, juga diperlukan kesesuaian dan kepekaan dalam memberikan sebuah dukungan sosial kepada individu yang membutuhkan. Dari sisi penerima, individu yang mengalami stressor seperti penderita TB Paru, seringkali merasakan ketidak seimbangan emosional yang menyebabkan individu bingung dan tidak menyadari bahwa kepedulian yang diberikan dari orang-orang sekitar adalah sebagai bentuk bantuan. Sedangkan dari sisi pemberi dukungan sosial, seringkali tidak mengerti tepatnya jenis dukungan apa yang dibutuhkan oleh penderita TB Paru. Hal ini mengakibatkan, tidak semua individu mendapatkan bantuan yang sebenarnya ia butuhkan.

Dari penelitian ini diketahui bahwa dukungan sosial memiliki pengaruh terhadap perilaku pencegahan penularan penyakit pada penderita TB Paru. Hal ini sudah sesuai dengan teori Sarafino \& Smith (1990) yang mengatakan bahwa dukungan sosial akan mempengaruhi perilaku kesehatan. Akan tetapi untuk mewujudkan perilaku pencegahan penularan penyakit, dibutuhkan lebih dari sekedar dukungan informasi saja. Masih adanya tiga komponen yang saling menunjang yang harus diperhatikan yaitu komponen kognitif merupakan representasi tentang apa yang dipercayai individu, komponen afektif merupakan perasaan yang menyangkut aspek emosional, dan komponen konatif merupakan aspek kecenderungan berperilaku tertentu sesuai dengan sikap yang dimiliki oleh seseorang (Rachmawati \& L., 2012).

\section{KESIMPULAN}

1. Responden (Penderita TB Paru) mayoritas adalah laki-laki yang telah memperoleh pendidikan dasar minimal SD, dan tergolong dalam kategori usia dewasa akhir yaitu antara 36-45 tahun. 
2. Perilaku pencegahan penularan penyakit pada penderita TB Paru sudah tergolong dalam kategori baik

3. Dukungan emosional dan informasi yang dirasakan oleh responden sudah tergolong dalam kategori baik.

4. Dukungan instrumental dan jaringan sosial yang dirasakan oleh responden tergolong dalam kategori kurang baik.

5. Dukungan Sosial yang dirasakan oleh responden tergolong dalam kategori baik.

6. Dukungan emosional, instrumental, informasi, dan jaringan sosial memiliki hubungan positif yang kuat terhadap perilaku pencegahan penularan penyakit dengan kontribusi masing-masing sebesar 55,55\%, 5,31\%, 21,21\%, dan $17,93 \%$.

7. Dukungan sosial memberikan pengaruh yang signifikan terhadap perilaku pencegahan penularan penyakit pada penderita TB Paru.

\section{SARAN}

Berdasarkan pengkajian hasil penelitian di lapangan maka penulis bermaksud memberkan saran yang mudah-mudahan dapat bermanfaat bagi Lembaga maupun bagi peneliti selanjutnya, yaitu sebagai berikut:

1. Bagi Puskesmas Perak Timur Surabaya

a. Sebaiknya menyediakan layanan komunitas penderita TB Paru sebagai wadah bagi penderita agar dapat berbagi keluh kesah dengan sesama penderita TB Paru.

b. Sebaiknya memberikan sosialisasi dan penyuluhan di masyarakat luas tentang pentingnya memberikan dukungan sosial kepada penderita TB Paru untuk meningkatkan peran masyarakat dalam terwujudnya perilaku pencegahan penularan penyakit yang baik pada penderita TB Paru

2. Bagi Masyarakat

Sebaiknya masyarakat berperan aktif dalam menyediakan berbagai dukungan sosial meliputi: a. Sebaiknya selalu menanyakan kabar terkini penderita; menanyakan kondisi kesehatan penderita; tidak menghindar dan menjauhi penderita; dapat menjadi tempat bercerita mengenai apapun baik kondisi kesehatan, isu terkini di masyarakat, maupun keluh kesah lainnya.

b. Tidak memberikan kesan menjauhi atau menghindar jika bertemu penderita TB Paru. Tetap berinteraksi seperti biasa, namun tetap dengan mengenakan masker. Jika melihat penderita tidak memakai masker, maka sebaiknya di tegur dengan baik.

c. Sebaiknya menawarkan bantuan untuk mengantar penderita ke fasilitas pelayanan kesehatan, atau mengerjakan aktivitas sehari-hari yang tidak mampu dilakukan pasien selama mengidap TB Paru.

d. Jika mampu, sebaiknya memberikan dukungan berupa makanan bergizi seperti susu; sayur; buah; dan daging rendah lemak kepada penderita TB Paru, atau memberikan masker agar penderita TB Paru merasa didukung untuk berperilaku mengenakan masker.

e. Sebaiknya sering mengingatkan penderita TB Paru tentang pentinya memakai masker, dan rutin berobat.

3. Bagi Peneliti Lain

a. Diharapkan mengembangkan apakah penelitian ini memiliki hubungan searah pula jika diterapkan terhadap penyakit menular dengan stigma negatif lain seperti TB MDR atau HIV.

b. Diharapkan dapat mengembangkan penelitian ini dalam bentuk kualitatif agar menyempurnakan teori pengaruh dukungan sosial terhadap penderita TB Paru. 


\section{DAFTAR PUSTAKA}

Bajunirwe, Francis., et al. (2009). Quality of life and social support among patients receiving antiretroviral therapy in Western Uganda. AIDS Care, 21(3), 271-279.

Berkman LF, Glass T, Brissette I, Seeman TE. From social integration to health: Durkheim in the new millennium. Soc Sci Med. 2000;51(6):843-857.

Deshmukh, Rajesh. D., et al. (2018). Social support a key factor for adherence to multidrug- resistant tuberculosis treatment. Indian Journal of Rheumatology, 65(1), 41-47.

Khamarko, Kevin., \& Myers, Janet. (2013). The Influence of Social Support on the Lives of HIV-Infected Individuals in Low- and Middle-Income Countries. World Health Organization, 1-40.

Martin JK, Pescosolido BA, Olafsdottir S, McLeod D. The construction of fear: Americans' preferences for social distance from children and adolescents with mental health problems. J Health Soc Behav.
2007;48(1):50-67.

Paz-soldán, Valerie., et al. (2013). The Provision Of And Need For Social Support Among Adult And Pediatric Patients With Tuberculosis In Lima , Peru: A Qualitative Study. BMC Health Services Research 13:290

Phelan, Jo C., Link, Bruce G., \& Tehranifar, Parisa. (2010). Social Conditions as Fundamental Causes of Health Inequalities: Theory, Evidence, and Policy Implications. Journal of Health and Social Behavior, 51(1_suppl), S28-S40.

Sarafino, Edward P., \& Smith, Timothy W. (1990). Health Psychology: Biopsychosocial Interactions-Seventh Edition (7th Editio; Christopher Johnson, Ed.). Hoboken: John Wiley \& Sons, Inc.

Tsai, Alexander C., et al. (2012). Food insecurity, depression and the modifying role of social support among people living with HIV/AIDS in rural Uganda. Social Science and Medicine, 74(12), 2012-2019 